\title{
Gene Transfer into the Rat Renal Glomerulus via a Mesangial Cell Vector: Site-specific Delivery, In Situ Amplification, and Sustained Expression of an Exogenous Gene In Vivo
}

\author{
Masanori Kitamura, Shirley Taylor, Robert Unwin, Stephen Burton, Fujio Shimizu, ${ }^{\star}$ and Leon G. Fine \\ Department of Medicine and Institute of Urology and Nephrology, University College London Medical School, London WC1E 6JJ, \\ United Kingdom; and * Department of Immunology, Institute of Nephrology, Niigata University School of Medicine, Niigata 951, Japan
}

\begin{abstract}
To evaluate the pathophysiological function of specific molecules in the renal glomerulus, selective, sustained, and modifiable expression of such molecules will be required. Towards achieving this end, we devised a gene transfer system using the glomerular mesangial cell as a vector for gene delivery. A reporter gene which encodes bacterial $\beta$-galactosidase was introduced into cultured rat mesangial cells, and the stable transfectants were transferred into the rat kidney via the renal artery, leading to selective entrapment within the glomeruli. In the normal kidney, the reporter cells populated into $57 \pm 13 \%$ of glomeruli site specifically, and the expression of $\beta$-galactosidase was sustained for 4 wk and declined thereafter. Within the glomerulus, some of the reporter cells remained in the glomerular capillaries, while others repopulated the mesangial area and, in part, extended their cytoplasmic processes toward the surrounding capillaries. When the cells were transferred into glomeruli subjected to transient mesangiolysis induced by monoclonal antibody $1-22-3$, in situ expression of $\beta$-galactosidase was amplified 7-12-fold, and the enhanced level of expression continued for up to 8 wk. The mesangial cell vector system thus achieves site-specific delivery of an exogenous gene into the glomerulus and is amenable to in situ amplification and sustained expression by preconditioning of the target site. (J. Clin. Invest. 1994. 94:497-505.) Key words: genetic engineering - retrovirus $\bullet \boldsymbol{\beta}$-galactosidase • cell transplantation • gene therapy
\end{abstract}

\section{Introduction}

Glomerular disease is one of the major causes of chronic renal failure. During the past $5 \mathrm{yr}$, various molecules have been implicated as mediators of glomerular injury (1-3). However, the majority of studies have been based on in vitro observations or on techniques used to detect gene expression or gene products in the affected tissue, without assessing the direct effect of such

This work was presented at the 26th Annual Meeting of the American Society of Nephrology in Boston, MA on 14-17 November 1993.

Address correspondence to Masanori Kitamura, M.D., Department of Medicine, University College London Medical School, The Rayne Institute, 5 University Street, London WC1E 6JJ, United Kingdom.

Received for publication 12 January 1994 and in revised form 1 April 1994.

J. Clin. Invest.

(c) The American Society for Clinical Investigation, Inc.

0021-9738/94/08/0497/09 \$2.00

Volume 94, August 1994, 497-505 molecules on the generation or repair of injury in vivo. An important challenge in this field will be to elucidate which mediators are pivotal in different types of glomerular damage using appropriate in vivo systems.

To identify the molecules involved in glomerular injury and repair, direct injection of bioactive substances or conventional gene transfer vectors, i.e., viral vectors or liposomes, into the circulation could be a possible approach $(4,5)$. However, this route would affect not only the glomerulus but other sites within the kidney, particularly the vasculature, as well as other organs. Use of transgenic animals has the limitation that there is a need for cell type-specific regulatory elements which allow the transgene to be expressed in the glomerulus. Currently, therefore, there are no systems appropriate for the purpose of modulating glomerular function site specifically for a sustained period. In this report, we describe an approach which achieves site-specific delivery and sustained expression of a foreign gene in the glomerulus using an ex vivo gene transfer system.

Gene transfer has been effected into various organs including bone marrow, skin, brain, muscle, lung, liver, artery, heart, kidney, and joint (5-9). In these cases, exogenous genes have been applied to the target organ or tissue by direct injection or local instillation of materials. In the kidney, however, the glomeruli are small structures (100-200 $\mu \mathrm{m}$ in diameter) scattered throughout the renal cortex $\left(3 \times 10^{4}-1 \times 10^{6}\right.$ glomeruli/ kidney) (10) and, therefore, cannot be gained access by these conventional approaches. Access via the renal circulation would be a reasonable approach, but in this case the entire renal vasculature may be affected. To restrict the site of gene introduction to the glomerulus, we used the glomerular mesangial cell as a vector for gene delivery. In the rat glomerulus, the diameter of the capillaries ranges from 5 to $25 \mu \mathrm{m}$ (11). Since the diameter of cultured rat mesangial cells ranges between 15 and $25 \mu \mathrm{m}$, cells injected into the renal circulation are entrapped within the glomerular capillaries. Using genetically engineered mesangial cells, we introduced the bacterial $\beta$-galactosidase gene $(\text { LacZ })^{1}$ into the glomerulus in vivo. By inducing a selective local stimulus to transient mesangial proliferation before the introduction of these cells, we successfully amplified the product of the exogenous gene and achieved its sustained expression within the glomerulus.

\section{Methods}

General experimental strategy. The gene which encodes for bacterial $\beta$-galactosidase ( $\mathrm{LaCZ}$ ) was introduced into rat mesangial cells in vitro,

1. Abbreviations used in this paper: AXG\%, percentage of glomerular area stained by X-gal; BAG, $\beta$-gal-at-gag; DMSA, di-mercapto-succinic acid; LacZ, bacterial $\beta$-galactosidase gene; LTR, long terminal repeat; neo, neomycin phosphotransferase gene; $\mathrm{Up} / \mathrm{Ucr}$ ratio, ratio of urinary protein concentration to urinary creatinine concentration; X-gal (XG), 5-bromo-4-chloro-3-indolyl $\beta$-D-galactopyranoside. 
and the cells were transferred into the rat kidney via renal artery injection. After $4 \mathrm{~h}, 1,2,4,8$, and $14 \mathrm{wk}$, both kidneys were removed and processed for glomerular isolation and tissue sections, and the expression of the gene product was examined histochemically. To amplify the introduced gene and its product in situ, the glomerulus was "preconditioned" using a monoclonal antibody 1-22-3 which causes mesangiolysis followed by transient and specific replication of mesangial cells, thereby providing a suitable microenvironment for vector cell replication.

Establishment and characterization of a reporter mesangial cell clone, $R M 4 / B G 715$. A $\beta$-gal-at-gag (BAG) plasmid (12) which introduces $L a c Z$ and neomycin phosphotransferase gene (neo) was transfected into a helper-free ecotropic packaging line, $\Omega E$ (13) (gift of Dr. H. Land, Imperial Cancer Research Fund), by electroporation, and replication-defective BAG virus was prepared from conditioned media of stable transfectants as described previously (14). The titer of the prepared virus was $\sim 4.4 \times 10^{4} \mathrm{X}$-gal $\mathrm{CFU} / \mathrm{ml}$, assessed by an NIH3T3 cell infection assay (14). No replication-competent virus was detected in this viral stock.

Rat mesangial cells were cultured from isolated renal glomeruli of a male Sprague-Dawley rat (body wt $250 \mathrm{~g}$ ) as described before (15). In brief, isolated glomeruli (purity $\sim 95 \%$ ) were cultured in DME (GIBCO BRL, Gaithersburg, MD) supplemented with $100 \mathrm{U} / \mathrm{ml}$ of penicillin $\mathrm{G}, 100 \mu \mathrm{g} / \mathrm{ml}$ of streptomycin, $0.25 \mu \mathrm{g} / \mathrm{ml}$ of amphotericin B, and $15 \%$ FCS. Outgrowing cells were subcultured and maintained in 10\% FCS/DME. After the fourth passage, the cells $\left(5 \times 10^{5}\right)$ were cultured on a 100-mm dish and were infected with $50 \mu \mathrm{l}$ of BAG virus in the presence of $8 \mu \mathrm{g} / \mathrm{ml}$ of Polybrene (Sigma Immunochemicals, St. Louis, MO) (14). $2 \mathrm{~d}$ later, selection of stable infectants was started in the presence of neomycin analogue G418 (Sigma Immunochemicals; $0.8 \mathrm{mg} / \mathrm{ml}$ ).

A high $\beta$-galactosidase-expressing clone, RM4/BG715, was selected from the neomycin-resistant mesangial cells using the X-gal (5bromo-4-chloro-3-indolyl $\beta$-D-galactopyranoside) assay to evaluate expression levels (8). Resistant clones were fixed in $0.5 \%$ glutaraldehyde, $2 \mathrm{mM} \mathrm{MgCl}_{2}$, and $1.25 \mathrm{mM}$ EGTA in PBS for $10 \mathrm{~min}$ at room temperature. After washing repeatedly, cells were incubated at $37^{\circ} \mathrm{C}$ for $2 \mathrm{~h}$ in $\mathrm{X}$-gal solution containing $1 \mathrm{mg} / \mathrm{ml} \mathrm{X-gal} \mathrm{(Sigma} \mathrm{Immunochemicals),}$ $5 \mathrm{mM} \mathrm{K}_{3} \mathrm{Fe}(\mathrm{CN})_{6}, 5 \mathrm{mM} \mathrm{K} \mathrm{K}_{4} \mathrm{Fe}(\mathrm{CN})_{6} \cdot 3 \mathrm{H}_{2} \mathrm{O}, 2 \mathrm{mM} \mathrm{MgCl}, 0.01 \%$ sodium desoxycholate, and $0.02 \% \mathrm{NP}-40$ in PBS (pH 7.4). The clone that exhibited the most intense blue color, RM4/BG715, was used as the reporter cell. The cells were expanded and stored in liquid nitrogen until use. A $\beta$-galactosidase-negative clone, RM4-4, was also established from the original culture pool of mesangial cells by a limiting dilutional method.

To confirm the mesangial cell phenotype of the reporter cell, the appropriate morphological features, and staining for desmin, $\alpha$-smooth muscle actin and Thy 1-associated antigen were sought. Antibodies used were: rabbit antidesmin antiserum (Sigma Immunochemicals; 1:20 dilution), mouse anti-mesangial cell monoclonal antibody 1-22-3 (16) (1:20 dilution), mouse anti- $\alpha$-smooth muscle actin monoclonal antibody (Sigma Immunochemicals; 1:200 dilution), goat anti-rabbit immunoglobulins FITC (Sigma Immunochemicals; 1:32 dilution), and goat anti-mouse immunoglobulins FITC (Sigma Immunochemicals; 1:50 dilution ).

To confirm the successful introduction of the exogenous genes into the reporter cell, the expression of neo as well as LacZ was examined by Northern hybridization. Confluent cultures of RM4/BG715 and the original mesangial cells, RM4, were harvested, and total RNA was extracted by a single-step method (17). Northern hybridization was performed as described previously (18). The RNA samples (10 $\mu \mathrm{g} /$ lane) were electrophoresed on a $1.2 \%$ agarose gel containing $10 \%$ formaldehyde and transferred onto nitrocellulose membranes (Schleicher \& Schuell, Dassel, Germany). As probes, a 3.1-kb BamHI fragment of LacZ and a 1.3-kb HindIII/EcoRI fragment of neo, derived from BAG, were labeled with $\left[{ }^{32} \mathrm{P}\right] \mathrm{dCTP}$ using a random priming method (19). The membranes were hybridized with probes at $65^{\circ} \mathrm{C}$ for $16 \mathrm{~h}$ in a solution containing $4 \times \mathrm{SSC}(600 \mathrm{mM}$ sodium chloride, $60 \mathrm{mM}$ sodium citrate), $5 \times$ Denhardt's solution, $10 \%$ dextran sulfate, and $100 \mu \mathrm{g} / \mathrm{ml}$ herring sperm DNA. The hybridized membranes were washed four times in $0.1 \times \mathrm{SSC} / 0.1 \% \mathrm{SDS}$ at $65^{\circ} \mathrm{C}$ and exposed to a Kodak XAR film with intensifying screens for $4 \mathrm{~d}$ at $-80^{\circ} \mathrm{C}$.

Reporter cell transfer into normal kidneys. 23 adult male SpragueDawley rats (body wt $250-500 \mathrm{~g}$ ) were anesthetized with an intraperitoneal injection of hypnorm-diazepam mixture. The left kidney was exposed through a left flank incision, separated from the surrounding fatty tissue and the adrenal gland, and immobilized in a kidney cup. The renal artery was then exposed and separated from the renal vein, and a cotton thread was passed around the proximal site of the renal artery. Confluent 7-17th passage RM4/BG715 cells $\left(0.5-2.5 \times 10^{6}\right.$ cells) were trypsinized, washed once, suspended in $700 \mu \mathrm{l}$ of DME, and injected into the left renal artery using a 27 -gauge needle at a rate of $40-100 \mu \mathrm{l} / \mathrm{s}$. To avoid bleeding after injection, the renal artery was constricted with a thread for 1-10 min and then allowed to reperfuse. After $4 \mathrm{~h}, 1,2,4,8$, and $14 \mathrm{wk}$, both kidneys were removed and processed for glomerular isolation and for frozen, paraffin, and resin sectioning. Blood and urine were also sampled and analyzed for creatinine and total protein concentrations.

Reporter cell transfer into kidneys subjected to mesangial regeneration. To amplify the introduced gene and its product within the glomerulus, we aimed to create a suitable microenvironment for transient and specific replication of the reporter cells. For this purpose, we used an anti-mesangial cell monoclonal antibody, 1-22-3 $(16,20)$, which recognizes the Thy 1-associated molecule on the surface of rat mesangial cells. In the rat kidney, this epitope specifically localizes on the mesangial cells. When 1-22-3 is injected into the venous circulation, therefore, selective mesangial damage occurs within $24 \mathrm{~h}$, followed by transient and specific replication of surviving mesangial cells resulting in the reconstruction of the normal glomerulus. In this model, maximum proliferation of mesangial cells is observed at days 4-6.

Monoclonal antibody 1-22-3 was prepared from ascitic fluid in mice primed with 2,6,10,14-tetramethylpentadecane as described previously (21). The fluid was precipitated with $50 \%$ ammonium sulphate, dialyzed with PBS for $2 \mathrm{~d}$, lyophilized, and stored at $4^{\circ} \mathrm{C}$ until use. The antibody was dissolved in PBS at a final concentration of $500 \mu \mathrm{g} / \mathrm{ml}$, and an aliquot of $1 \mathrm{ml}$ was injected into the tail vein. The reporter cells were transferred into the kidneys of 27 rats $3 \mathrm{~d}$ after the 1-22-3 treatment. After $4 \mathrm{~h}, 1,2,4$, and $8 \mathrm{wk}$, both kidneys, blood, and urine were sampled and analyzed as described above.

In some experiments, reporter cells were treated with $0.2 \mu \mathrm{g} / \mathrm{ml}$ of mitomycin C (Sigma Immunochemicals) for $20 \mathrm{~h}$ and then transferred into the kidney. In vitro, mitomycin $C$ treatment inhibited the proliferation of reporter cells irreversibly but did not affect the expression of $\beta$ galactosidase during a 3-wk period of observation.

Analysis of gene transfer efficiency in the kidneys by X-gal assay. To examine the efficiency and site specificity of gene delivery, the Xgal assay was performed on frozen sections from both kidneys and lungs as well as on isolated glomeruli. For the preparation of frozen sections, tissues were fixed in $2 \%$ paraformaldehyde, $0.2 \%$ glutaraldehyde, $2 \mathrm{mM}$ $\mathrm{MgCl}_{2}$, and $1.25 \mathrm{mM}$ EGTA in $0.1 \mathrm{M}$ Pipes buffer ( $\mathrm{pH} \mathrm{6.9)}$ at $4^{\circ} \mathrm{C}$ overnight. The tissues were then transferred into $30 \%$ sucrose and 2 $\mathrm{mM} \mathrm{MgCl}$ in PBS, incubated overnight, embedded in compound, and sectioned (6- $\mu \mathrm{m}$ slice) by a cryostat onto gelatine-coated slides. Before the X-gal assay was commenced, the tissue sections were postfixed at $4^{\circ} \mathrm{C}$ for $10 \mathrm{~min}$. Glomeruli were isolated as described above, fixed in $2 \%$ paraformaldehyde $/ 0.2 \%$ glutaraldehyde buffer at $4^{\circ} \mathrm{C}$ overnight, and then subjected to the $\mathrm{X}$-gal assay.

The X-gal assay on frozen sections and isolated glomeruli was performed as follows: fixed materials were washed by cold PBS containing $2 \mathrm{mM} \mathrm{MgCl} 2$ repeatedly, transferred into detergent solution $(2 \mathrm{mM}$ $\mathrm{MgCl}_{2}, 0.01 \%$ sodium desoxycholate, and $0.02 \% \mathrm{NP}-40$ in PBS) for $10 \mathrm{~min}$ on ice, and then incubated in $1 \mathrm{mg} / \mathrm{ml}$ of $\mathrm{X}$-gal solution (as described above) at $37^{\circ} \mathrm{C}$ for $2 \mathrm{~h}$. The incubation time was critical because longer incubation allowed endogenous $\beta$-galactosidase activity in glomerular macrophages ( $\sim 12 \mathrm{~h}$ of incubation) as well as in tubular epithelial cells ( $\sim 3-4 \mathrm{~h}$ of incubation) to emerge. To stop the enzy- 

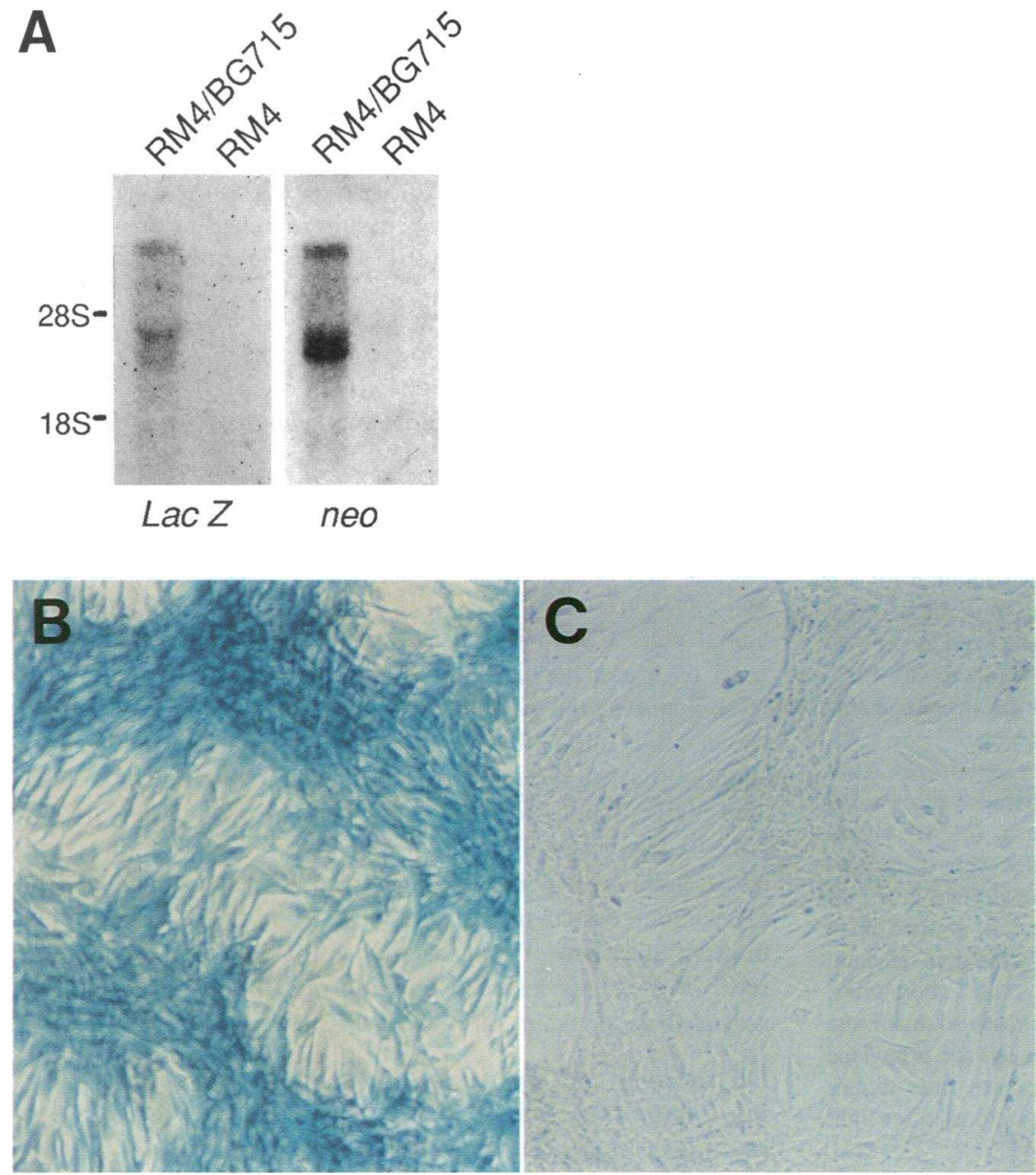

Figure 1. Expression of exogenous genes in a reporter mesangial cell clone, RM4/BG715.

$(A)$ Northern blot analysis of bacterial $\beta$-galactosidase ( $\mathrm{LacZ}$ ) and neomycin phosphotransferase ( $n e o$ ) mRNAs in BAG virus-infected RM4/BG715 and uninfected RM4 mesangial cells. Positions of $28 \mathrm{~S}$ and $18 \mathrm{~S}$ ribosomal

RNAs are shown on the left. ( $B$ and $C$ ) Expression of $\beta$-galactosidase in RM4/BG715 (B) and RM4 $(C)$ examined by X-gal assay. Blue color shows the expressed $\beta$-galactosidase activity. The undulating hill and valley appearance, typical of mesangial cells, is evident in both infected and uninfected cells. matic reaction, isolated glomeruli were washed in cold PBS several times and kept in $10 \%$ formaldehyde. The frozen sections were immediately washed in PBS, counterstained with periodic acid-Schiff (PAS), dehydrated with ethanol, and mounted. The frozen sections were exam- ined by light microscopy. Isolated glomeruli were examined using a phase-contrast and/or light microscope without counterstaining.

To assess the efficiency of gene transfer, the percentage of X-galpositive glomeruli was determined. Amplification of the introduced gene
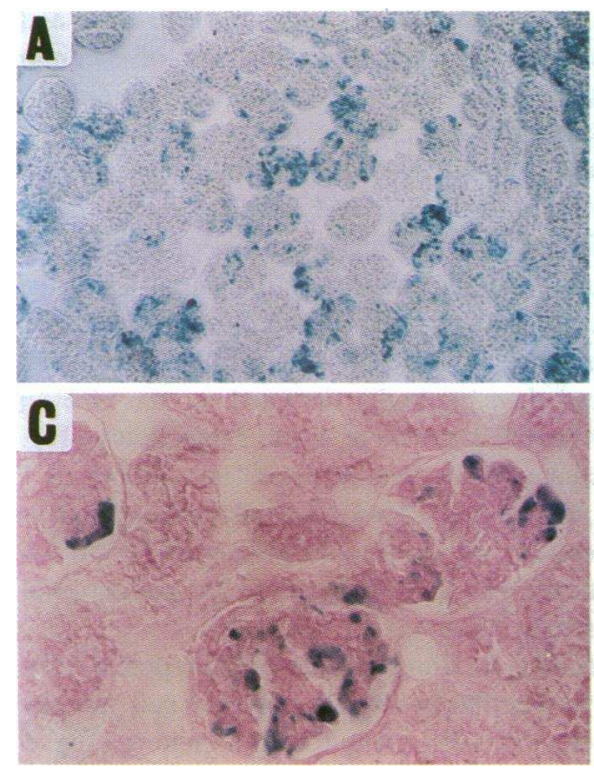
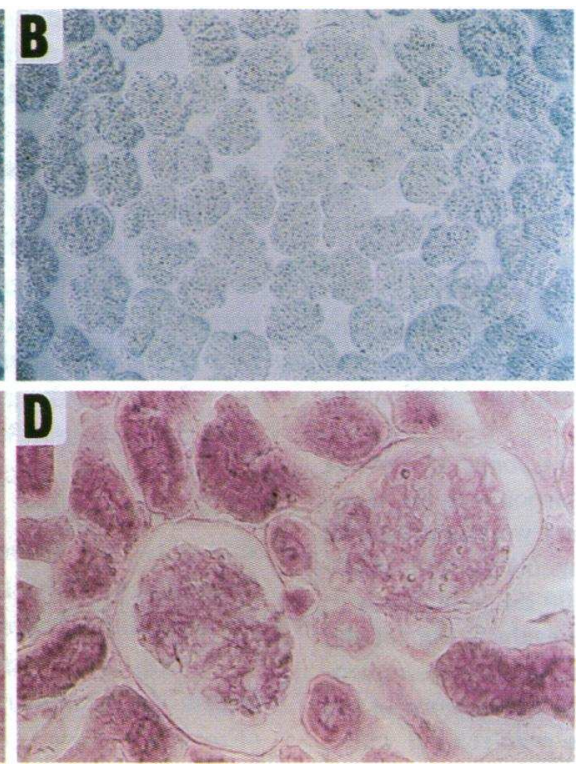

Figure 2. Expression of $\beta$-galactosidase $4 \mathrm{~h}$ after reporter cell transfer. ( $A$ and $B$ ) Phasecontrast micrograph of $\mathrm{X}$-gal-treated isolated glomeruli from injected kidney $(A)$ and contralateral kidney $(B) . \times 100$. $(C$ and $D)$ $X$-gal-treated frozen sections from injected kidney $(C)$ and contralateral kidney $(D)$. $\times 400$, PAS counterstaining. 
product was expressed quantitatively using an $\mathrm{X}$-gal ( $\mathrm{XG}$ ) score on isolated glomeruli. In each X-gal-positive glomerulus, the percentage of glomerular area stained by X-gal (AXG\%) was graded into four levels: $\sim 5 \%, 5 \sim 25 \%, 25 \sim 50 \%, 50 \sim 100 \%$, and the mean value per positive glomerulus was calculated: mean AXG $(\%)=(2.5 \times$ a $)$ $+(15 \times b)+(37.5 \times c)+(75 \times d) / a+b+c+d$, where $a, b, c$, and $\mathrm{d}$ are the number of $\mathrm{X}$-gal-positive glomeruli showing grades of $\sim 5 \%, 5 \sim 25 \%, 25 \sim 50 \%$, and $50 \sim 100 \%$, respectively. The X-gal score per kidney was calculated using the following formula:

$\mathrm{XG}$ score $=$ mean $\mathrm{AXG}(\%) \times$ total positive glomeruli $(\%)$.

During the course of experiments, each X-gal score was compared with the mean value obtained at $4 \mathrm{~h}$ and expressed as a fold increase.

Histochemical analysis of reporter cell location in the glomerulus. To identify the location of the reporter cells within the glomerulus, we performed histochemical analyses of the injected kidney. To prepare $\mathrm{X}$-gal-paraffin sections, injected kidneys were fixed by $2 \%$ paraformaldehyde $/ 0.2 \%$ glutaraldehyde buffer at $4^{\circ} \mathrm{C}$ overnight. The cortex was cut into small pieces and reacted in X-gal solution for $3 \mathrm{~h}$ at $37^{\circ} \mathrm{C}$ with agitation. The longer incubation was used to allow $\mathrm{X}$-gal solution to permeate into the tissues. The tissues were fixed again with $10 \%$ formaldehyde at room temperature overnight, washed with PBS, and embedded in paraffin. The sections prepared $(3 \mu \mathrm{m})$ were counterstained with PAS and examined using a light microscope.

Resin sections were also prepared using X-gal-treated tissues. After allowing the $\mathrm{X}$-gal reaction to proceed for $3 \mathrm{~h}$, the tissues were washed with PBS and postfixed with $2.5 \%$ glutaraldehyde in $0.1 \mathrm{M}$ sodium cacodylate buffer $\left(\mathrm{pH} \mathrm{7.2)}\right.$ at $4^{\circ} \mathrm{C}$ overnight. Samples were then incubated in $1 \%$ osmium tetroxide $/ 1.5 \%$ potassium cyanoferrate in $0.1 \mathrm{M}$ sodium cacodylate buffer at room temperature for $1 \mathrm{~h}$, washed three times with $0.1 \mathrm{M}$ sodium cacodylate buffer, dehydrated in ethanol, and embedded in Spurr's embedding medium (TAAB Laboratories, Berkshire, United Kingdom). Spurr's medium was chosen so that tissue can be processed from $100 \%$ ethanol without the need for propylene oxide which causes dissolution of the $\mathrm{X}$-gal precipitates from tissues (22). Sections $(0.5 \mu \mathrm{m})$ stained with toluidine blue were used for light microscopic analyses.

Effect of cell transfer on the structure and function of the kidney. For histopathological analysis, paraffin sections $(5 \mu \mathrm{m})$ of the kidneys fixed in $10 \%$ formaldehyde were counterstained with PAS and hematoxylin.

To estimate the effect of cell transfer on the single kidney function, we used ${ }^{99 \mathrm{~m}} \mathrm{Tc}$ di-mercapto-succinic acid (DMSA). Since circulating ${ }^{99 m}$ Tc DMSA is excreted by glomerular filtration and taken up by the tubular cells, its uptake is proportional to renal function (23). Reporter cells $\left(0.8-1.0 \times 10^{6}\right.$ cells $)$ were introduced into the left kidneys of six rats via the renal artery. As a sham injection, $700 \mu \mathrm{l}$ of DME was used in two rats. After $1 \mathrm{wk},{ }^{99 \mathrm{~m}} \mathrm{Tc}$ DMSA $(50 \mathrm{kBq} / \mathrm{rat})$ was injected into the tail vein of anesthetized rats. $2 \mathrm{~h}$ later, both kidneys were removed, and the radioactivity in each was counted separately.

The effect of cell transfer on proteinuria was evaluated as follows. The ratio of urinary protein concentration to urinary creatinine concentration (Up/Ucr ratio) was used to express the degree of proteinuria since this value is relatively independent of changes in urine volume (24). To determine the normal range of Up/Ucr ratio in adult rats, urine samples were obtained from 22 normal male adult Sprague-Dawley rats. Urine creatinine concentration was measured by autoanalyzer (Beckman Instruments, Inc., Fullerton, CA), and urinary protein concentration was assessed using the Bradford assay (25).

Evaluation of humoral and cellular immune response to reporter cells. To estimate the possible humoral immune response to the transferred cells, reporter cells fixed with cold methanol were reacted with undiluted normal rat serum or test sera and then incubated with FITCconjugated rabbit anti-rat immunoglobulins (1:100 dilution; Southern Biotechnology Associates, Birmingham, AL). To evaluate the cellular immune response, infiltration of $\mathrm{T}$ lymphocytes and monocytes/macrophages into the glomeruli was examined using frozen sections of the injected kidneys after 2 and 4 wk. Fixed sections were reacted with a monoclonal antibody against rat T lymphocytes (MRC OX-52; Serotec Ltd., Oxford, United Kingdom ) (1:100 dilution) or rat monocytes/macrophages (ED1; Serotec Ltd) (1:500 dilution) and then incubated with goat anti-mouse immunoglobulins FITC ( 1:50 dilution; Sigma Immunochemicals). Immunofluorescence was examined under a fluorescence microscope.

Statistical analysis. Statistical analysis was performed using the Mann-Whitney test (nonparametric method) to compare data in different groups of animals. $P$ value of $<0.05$ was used to indicate a statistically significant difference.

\section{Results}

\section{Characterization of the reporter mesangial cell clone,} $R M 4 / B G 715$

Using replication-defective BAG virus, we established a neomycin-resistant reporter clone, RM4/BG715. Northern analysis detected the transcripts of the introduced genes, 4.0-kb LacZ and 3.6-kb neo, in RM4/BG715 but not in the uninfected mesangial cells RM4 (Fig. $1 \mathrm{~A}$ ). X-gal analysis revealed a high level of $\beta$-galactosidase activity in this reporter clone (Fig. 1 $B$ ) but not in the uninfected cells (Fig. 1 C). RM4/BG715 showed the "hill and valley" formation (Fig. $1 B$ ) and positive staining for desmin, $\alpha$-smooth muscle actin, and Thy 1 -associated antigen (not shown) seen in cultured rat mesangial cells. No evidence of transformation was observed in the reporter cell as assessed by its growth activity in soft agar (26), and no replication-competent virus was detected in the conditioned medium of this clone. The mesangial cell phenotypes and the high level of $\beta$-galactosidase expression of RM4/BG715 were observed to be constant through 7-17 passages.

\section{Distribution and kinetics of reporter cells after transfer into the normal kidney}

Confluent reporter cells were trypsinized, suspended in DME, and injected into the left kidney via the renal artery. $4 \mathrm{~h}$ after injection, $17-62 \%(34 \pm 8 \%$; mean \pm SE, $n=6)$ of isolated glomeruli were positive for X-gal staining (Fig. $2 A$ ). Reporter cells were not detected in the glomeruli from the contralateral kidneys (Fig. $2 \mathrm{~B}$ ). X-gal analysis of the frozen sections revealed that the reporter cells had accumulated in the glomerulus in a site-specific manner (Fig. $2 C$ ). No X-gal-positive cells were detected in afferent or efferent arteriole or in interstitial capillaries. Likewise, the contralateral kidneys (Fig. $2 D$ ) and lungs (not shown) were also negative. Injection of medium alone or of a $\beta$-galactosidase-negative clone, RM4-4, did not induce any $\mathrm{X}$-gal-positive areas in the injected kidney (data not shown ), indicating that the observed enzymatic activity was derived exclusively from the introduced $L a c Z$ gene.

The kinetics of the $\beta$-galactosidase expression during the course of experiments was studied. During the initial $4 \mathrm{wk}$, the mean percentages of $\mathrm{X}$-gal-positive glomeruli were sustained above $30 \%$; the percentage increased to $57 \pm 13 \%$ (mean \pm SE, $n=5$ ) at $1 \mathrm{wk}$, and then gradually declined to $35 \pm 14 \%$ ( $n$ $=4)$ at $2 \mathrm{wk}$ and $30 \pm 16 \%(n=4)$ at $4 \mathrm{wk}$, respectively (Fig. 3 ). Maximum efficiency, $83 \%$, was achieved in a kidney at 1 wk after injection. After 8 and $14 \mathrm{wk}, \beta$-galactosidase expression was only detected in the occasional glomerulus $(\sim 6 \%)$. $\beta$-Galactosidase activity was never detected in the glomeruli of the contralateral kidneys.

Using X-gal paraffin sections, we detected reporter cells within the glomerular capillaries even 1 wk after cell transfer (Fig. $4 A$ ). Some cells extended along the endothelium (Fig. 4 


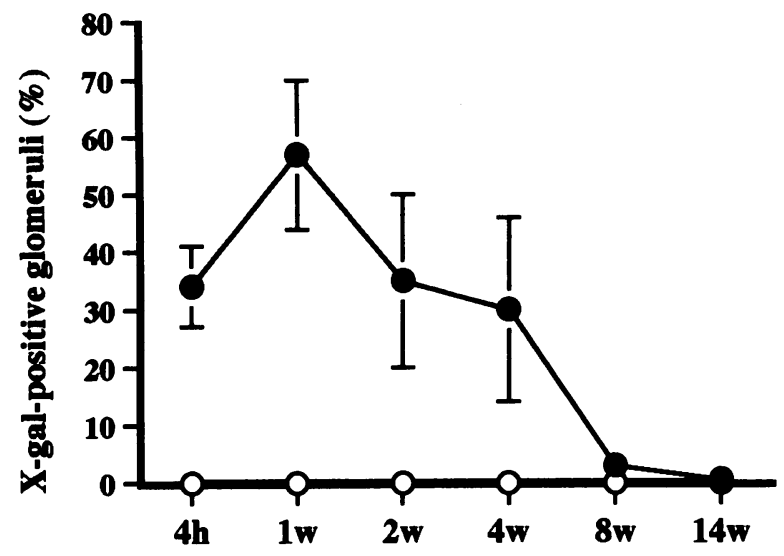

Figure 3. Kinetics of $\beta$-galactosidase expression in glomeruli after reporter cell transfer. Isolated glomeruli from injected or contralateral kidneys were subjected to X-gal assay, and mean percentages of $\mathrm{X}$ gal-positive glomeruli were evaluated at $4 \mathrm{~h}, 1,2,4,8$, and $14 \mathrm{wk}$ after cell transfer. Closed circles, injection side; open circles, noninjection side. Means \pm SE.

$B$ ) or occupied the capillary lumens (Fig. $4 C$ ). However, other cells seemed to migrate within the glomerulus and make connections with each other (Fig. $4 \mathrm{D}$ ). Microscopic analysis of $\mathrm{X}$ gal-treated resin sections revealed that these cells, indeed, populated the mesangial area (Fig. 4, $E$ and $F$ ) and, at least in part, extended their cytoplasmic processes toward the surrounding capillaries not unlike the resident mesangial cells (Fig. $4 E$ ).

\section{Kinetics of reporter cells after transfer into kidneys} undergoing transient mesangial regeneration

Cells were transferred into regenerating glomeruli $3 \mathrm{~d}$ after the administration of monoclonal antibody 1-22-3. $4 \mathrm{~h}$ after cell injection, $21-67 \%(50 \pm 11 \%$; mean $\pm S E, n=4)$ of glomeruli were positive for $\mathrm{X}$-gal staining, with the distribution of the cells being as sparse as in the normal glomeruli (Fig. $5 A$ ). Within $7 \mathrm{~d}$, however, the $\beta$-galactosidase activity was amplified in situ, and the X-gal-positive areas were dramatically expanded (Fig. $5 \mathrm{~B}$ ). The regenerative state of the glomerulus improved the efficiency of gene introduction as well as the expression level of the gene product; the percentage of X-galpositive glomeruli per injected kidney increased from $34 \pm 8 \%$ in normal to $50 \pm 11 \%$ in regenerating kidneys at $4 \mathrm{~h}$, and from $57 \pm 13 \%$ to $75 \pm 4 \%$ at 1 wk. Again, the reporter cells were neither detected in other portions of the injected kidneys (Fig. $5 C$ ) nor in the contralateral kidneys, except for one injected kidney where a small number of reporter cells was detected in the medullary interstitium. Transfer of the $\beta$-galactosidasenegative clone RM4-4 did not produce any X-gal positivity in the injected kidneys (Fig. $5 \mathrm{D}$ ), indicating that the enhanced enzyme expression was derived from the exogenous transgene.

In each glomerulus, expansion of the reporter cells progressed during the first $2 \mathrm{wk}$ and then reached a plateau (shown in Mean AXG (\%) in Table I). $\beta$-Galactosidase activity per kidney indicated by $\mathrm{X}$-gal score was also markedly increased during the first $2 \mathrm{wk}$, and the high level of expression (7-12fold increase compared with the 4-h score) continued for at least 8 wk (Fig. 6). In contrast to this result from isolated glomeruli, frozen sections of injected kidneys at 4 and 8 wk revealed evidence of glomerulosclerosis where $\mathrm{X}$-gal positivity had diminished.
To confirm that the increased expression of the exogenous gene was due to the replication of the transferred cells, we examined the kinetics of replication-defective reporter cells which were treated with mitomycin $C$. A suspension of the mitomycin-treated cells was injected into the regenerating kidneys $3 \mathrm{~d}$ after 1-22-3 treatment. After $7 \mathrm{~d}$, in contrast to the replication-competent cells (Fig. $7 \mathrm{~A}$ ), expansion of X-galpositive area of the glomerulus did not occur in the mitomycintreated cells (Fig. $7 \mathrm{~B}$ ); the percentage of X-gal-positive area in each glomerulus was $2.8 \pm 0.1 \%$ (mean $\pm \mathrm{SE}$ ) in the group of treated cells $(n=4)$ vs $27.5 \pm 5.2 \%$ in the untreated group ( $n$ $=5$ ). The X-gal score was $61 \pm 21$ (mean $\pm S E$ ) in mitomycintreated cells vs $2,014 \pm 288$ in untreated cells. These findings indicated that the increased expression of $\beta$-galactosidase was due to replication of the reporter cells.

\section{Effect of reporter cell transfer on the structure and function of the kidney}

Histological change. The majority of the glomeruli where reporter cells were transferred showed normal appearance at $4 \mathrm{~h}$ and $1 \mathrm{wk}$, except for the presence of entrapped cells within the capillaries. At 1 wk after cell transfer, the reporter cells typically occupied capillary lumens (Fig. $8 \mathrm{~A}$ ). Nodular remodeling of peripheral capillaries (Fig. $8 \mathrm{~B}$ ) or expansion of the glomerular tuft (Fig. $8 \mathrm{C}$ ) was occasionally detected at this stage. After 4 and $8 \mathrm{wk}$, however, increased cellularity and matrix expansion in glomeruli were observed in the two kidneys which exhibited the most prominent $\mathrm{X}$-gal staining (not shown). In four other kidneys examined, the glomerular alteration was modest, showing occasional nodular/segmental sclerosis or increased cellularity. At this stage, infiltration of mononuclear cells into the interstitium was detected even when histological change in the glomerulus was minor. The 1-22-3-treated glomeruli containing reporter cells, however, exhibited histological evidence of pronounced hypercellularity, matrix expansion, and glomerular hypertrophy at $1 \mathrm{wk}$ in association with expansion of the reporter cell population (Fig. $8 \mathrm{D}$ ). In contrast to the selflimiting course of 1-22-3-induced injury itself, the glomerular damage was progressive, and global or segmental sclerosis was observed in the glomeruli at 4 and $8 \mathrm{wk}$ (not shown). This progressive injury was not detected after the transfer of replication-defective cells which were pretreated with mitomycin C.

Single kidney function. Using ${ }^{99 \mathrm{~m}} \mathrm{Tc}$ DMSA uptake, the effect of reporter cell transfer on the function of injected kidneys was evaluated. $1 \mathrm{wk}$ after cell transfer, the function of the injected kidneys was $19.7 \pm 2.6 \%($ mean $\pm S E, n=6)$ lower than that of the noninjected side. Injection of medium alone did not induce any functional change, suggesting that the observed alteration was caused by the entrapped reporter cells.

Proteinuria. In the normal adult rats, the Up/Ucr ratio ranged from 0.02 to $0.52(0.23 \pm 0.03$, mean $\pm S E$ of 22 rats $)$. When the cells were transferred into the normal kidneys, the $\mathrm{Up} / \mathrm{Ucr}$ ratios were $0.32 \pm 0.06$ at $4 \mathrm{~h}, 0.11 \pm 0.08$ at $1 \mathrm{wk}$, $0.17 \pm 0.01$ at $2 \mathrm{wk}$, and $0.22 \pm 0.12$ at $4 \mathrm{wk}$, respectively. These values were not statistically different from normal. We next examined the effect of cell transfer on proteinuria in the 1-223 -treated kidneys. The anti-mesangial cell antibody induced transient proteinuria with peak on days 5-10 after the antibody injection. When the reporter cells were transferred into these kidneys, an enhanced and prolonged proteinuric response (not statistically different) was observed after $1 \mathrm{wk}$ ( $\mathrm{Up} / \mathrm{UCr}$ ratio: $0.59 \pm 0.22$ in reporter cell $[+]$ vs $0.37 \pm 0.10$ in reporter 


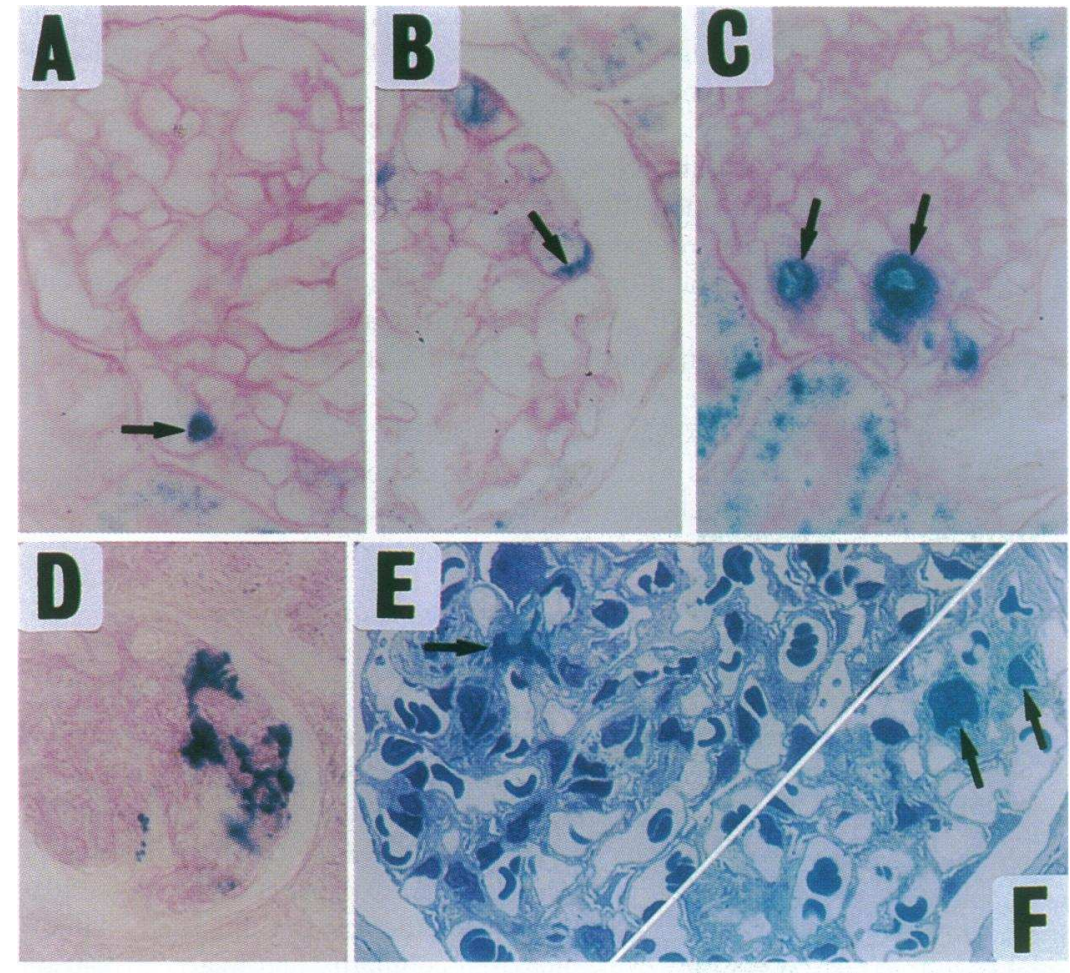

Figure 4. Localization of reporter cells within glomeruli 1 wk after cell transfer. $(A-C) \mathrm{X}$-gal paraffin sections counterstained with PAS, $(D) \mathrm{X}$-gal frozen section stained with PAS, $(E$ and $F)$ X-gal resin sections stained with toluidine blue. $\times 1,000$. Arrows indicate reporter cells in both an endothelial location $(A$ and $B)$ and mesangial location $(E$ and $F)$. cell $[-])$ and 2 wk $(0.57 \pm 0.26$ in cell $[+]$ vs $0.22 \pm 0.12$ in cell $[-])$.

\section{Humoral and cellular immune response to reporter cells}

To examine the humoral immune response in the recipient animals, we tested for the presence of circulating antibodies against the reporter cells. Immunoreactivity against the cells was not detected in the sera of the host animals during the course of experiments. To assess the cellular immune response, we further examined infiltrating cells in the injected kidneys. Using immunofluorescence, focal infiltration of $T$ lymphocytes and monocytes/macrophages in the glomeruli and the interstitium was observed 2 and 4 wk after cell transfer (data not shown).

\section{Discussion}

Using the cultured mesangial cell as a vector for gene delivery, we have devised a novel gene transfer system which targets a microscopic structure in the kidney, the glomerulus. This system has several advantages over conventional in vivo gene transfer methods which use viral vectors or liposomes, i.e., high effi-

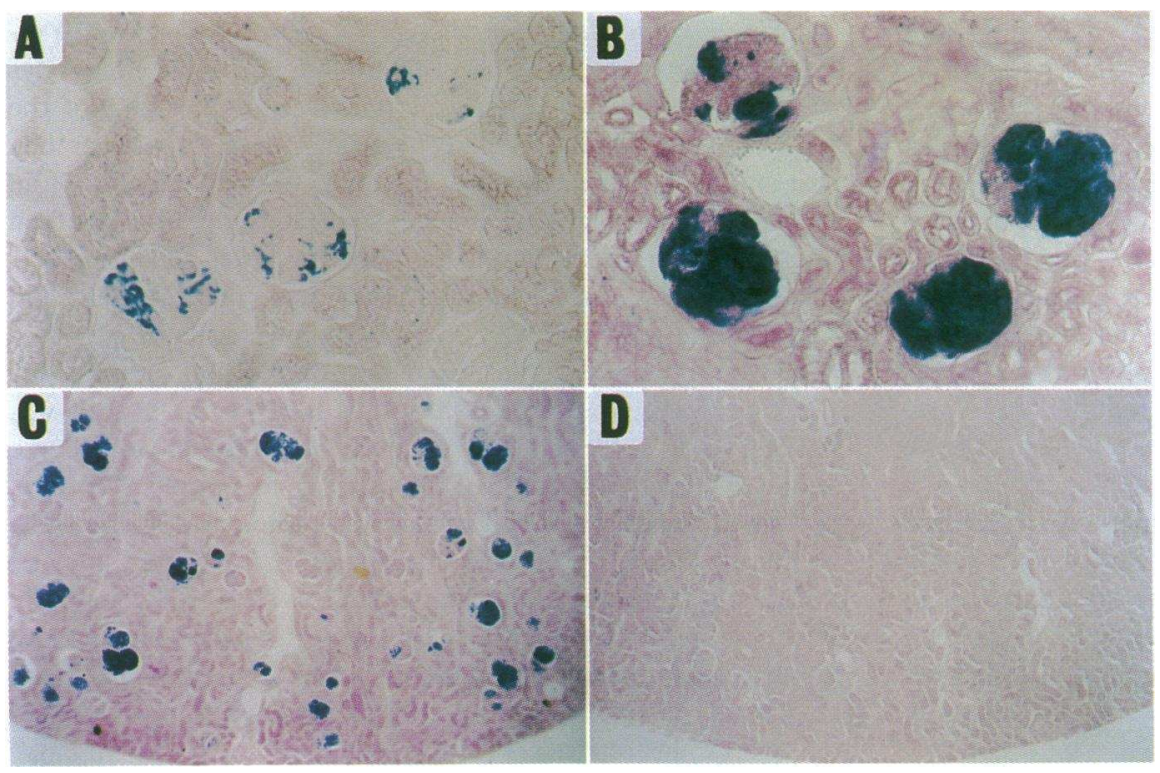

Figure 5. Amplification of $\beta$-galactosidase activity in glomeruli subjected to mesangial regeneration. $(A-C)$ Reporter cells were transferred into the kidneys exposed to antimesangial cell antibody (1-22-3) $3 \mathrm{~d}$ before transfer, and expression of $\beta$-galactosidase was examined after $4 \mathrm{~h}(A, \times 200), 1 \mathrm{wk}(B$, $\times 200)$, and 2 wk $(C, \times 40)$ using an X-gal assay of frozen sections. (PAS counterstaining). (D) $\beta$-Galactosidase-negative clone, RM4-4, was transferred into the kidney treated with 1-22-3, and the X-gal assay was performed after 1 wk $(\times 40)$. 
Table I. Amplification of $\beta$-Galactosidase Expression within the Glomerulus by Anti-Mesangial Cell Antibody 1-22-3

\begin{tabular}{|c|c|c|c|c|c|c|c|c|c|c|}
\hline \multirow[b]{2}{*}{ Term } & \multirow[b]{2}{*}{$n$} & \multicolumn{2}{|c|}{$\begin{array}{l}\text { Total positive } \\
\text { glomeruli (\%) }\end{array}$} & \multicolumn{4}{|c|}{ AXG (\%) } & \multirow{2}{*}{$\begin{array}{c}\text { Mean } \\
\text { AXG (\%) }\end{array}$} & \multirow{2}{*}{$\begin{array}{l}\text { XG } \\
\text { score }\end{array}$} & \multirow{2}{*}{$\begin{array}{c}\text { Fold } \\
\text { increase }\end{array}$} \\
\hline & & L & $\mathbf{R}$ & $\sim 5 \%$ & $\sim 25 \%$ & $\sim 50 \%$ & $\sim 100 \%$ & & & \\
\hline $4 \mathrm{~h}$ & 4 & $50 \pm 11$ & 0 & $78 \pm 4$ & $18 \pm 2$ & $5 \pm 3$ & 0 & $6.4 \pm 1.2$ & $283 \pm 43$ & - \\
\hline $1 \mathrm{wk}$ & 5 & $75 \pm 4$ & 0 & $19 \pm 3$ & $47 \pm 8$ & $15 \pm 2$ & $19 \pm 8$ & $27.5 \pm 5.2 *$ & $2014 \pm 288^{*}$ & $7.1 \pm 1.0$ \\
\hline $2 \mathrm{wk}$ & 4 & $61 \pm 12$ & 0 & $14 \pm 3$ & $17 \pm 4$ & $22 \pm 1$ & $47 \pm 7$ & $45.8 \pm 4.0^{*}$ & $2913 \pm 773 *$ & $10.3 \pm 2.8$ \\
\hline 4 wk & 4 & $53 \pm 11$ & 0 & $11 \pm 2$ & $24 \pm 7$ & $25 \pm 3$ & $40 \pm 9$ & $43.5 \pm 5.1 *$ & $2191 \pm 289 *$ & $7.8 \pm 1.0$ \\
\hline $8 \mathrm{wk}$ & 2 & $70 \pm 11$ & 0 & $14 \pm 9$ & $17 \pm 2$ & $22 \pm 1$ & $47 \pm 7$ & $46.3 \pm 5.1$ & $3272 \pm 890$ & $11.6 \pm 3.2$ \\
\hline
\end{tabular}

The reporter cells were transferred into the kidneys $3 \mathrm{~d}$ after the 1-22-3 treatment. After $4 \mathrm{~h}, 1,2,4$, and 8 wk, both kidneys were sampled, and percentages of X-gal-positive glomerulus were calculated using isolated glomeruli from injected kidneys ( $L$, left) or contralateral kidneys ( $R$, right). In each X-gal-positive glomerulus, AXG\% was graded into four levels: $\sim 5 \%, 5 \sim 25 \%, 25 \sim 50 \%, 50 \sim 100 \%$, and the mean value per positive glomerulus was calculated: Mean AXG $(\%)=(2.5 \times a)+(15 \times b)+(37.5 \times c)+(75 \times d) / a+b+c+d$, where a, b, c, and d are the number of X-gal-positive glomeruli showing grades of $\sim 5 \%, 5 \sim 25 \%, 25 \sim 50 \%$, and $50 \sim 100 \%$, respectively. The X-gal score (XG score) per kidney was calculated using the following formula: XG score $=$ Mean AXG (\%) $\times$ total positive glomeruli (\%). Each XG score was compared with the mean value obtained at $4 \mathrm{~h}$ and expressed as a fold increase. $* P<0.05$.

ciency and site specificity of gene delivery and stable expression of the introduced gene product. For example, compared with the recently reported hemagglutinating virus of Japan-liposome method which targets $15-35 \%$ of glomeruli and allows for gene expression over several days $(5,27)$, the mesangial cell vector system achieves higher efficiency ( $57 \%$ of total glomeruli, after $1 \mathrm{wk}$ ) and longer expression (4 wk) in the glomerulus. In combination with pretreatment of the kidney to render the mesangial cells proliferative, in situ amplification of the introduced gene product was achieved. A substantial advantage of using these genetically engineered cells is the convenience of the method, using, as it does, in vitro rather than in vivo transfection. This method allows for sophisticated cell engineering in vitro and will enable the transfer and expression of multiple genes for analysis of their composite interactions within the glomerulus:

After the cell transfer, we found that some of the cells remained within the glomerular capillaries. These cells would be ideally positioned to allow for diffusion of secreted foreign

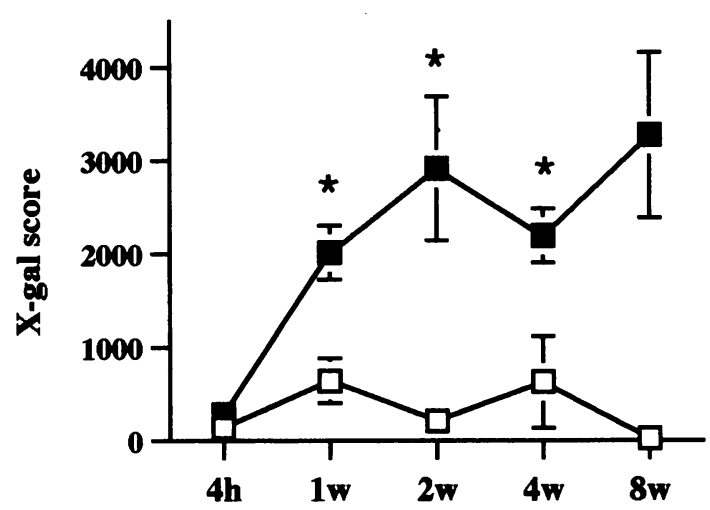

Figure 6. Semiquantitative assessment of $\beta$-galactosidase expression per injected kidney in normal and regenerating glomeruli. X-gal score was calculated using isolated glomeruli reacted with $\mathrm{X}$-gal, as noted in Methods. X-gal scores at 1, 2, 4, and 8 wk are expressed as means $\pm \mathrm{SE}$. Closed squares, kidneys pretreated with monoclonal antibody 1-22-3; open squares, untreated kidneys. Asterisks show statistical significance $(P<0.05)$ of differences between the groups at each time point. proteins throughout the glomerulus via the capillary lumen, endothelial fenestrate, and mesangial pathways (10). Importantly, we also found that some of the cells transferred repopulated the mesangial area presumably by migration. This implies that the vector cells can, at least in part, be incorporated into the glomerular architecture as constituents of a genetically engineered chimeric glomerulus.

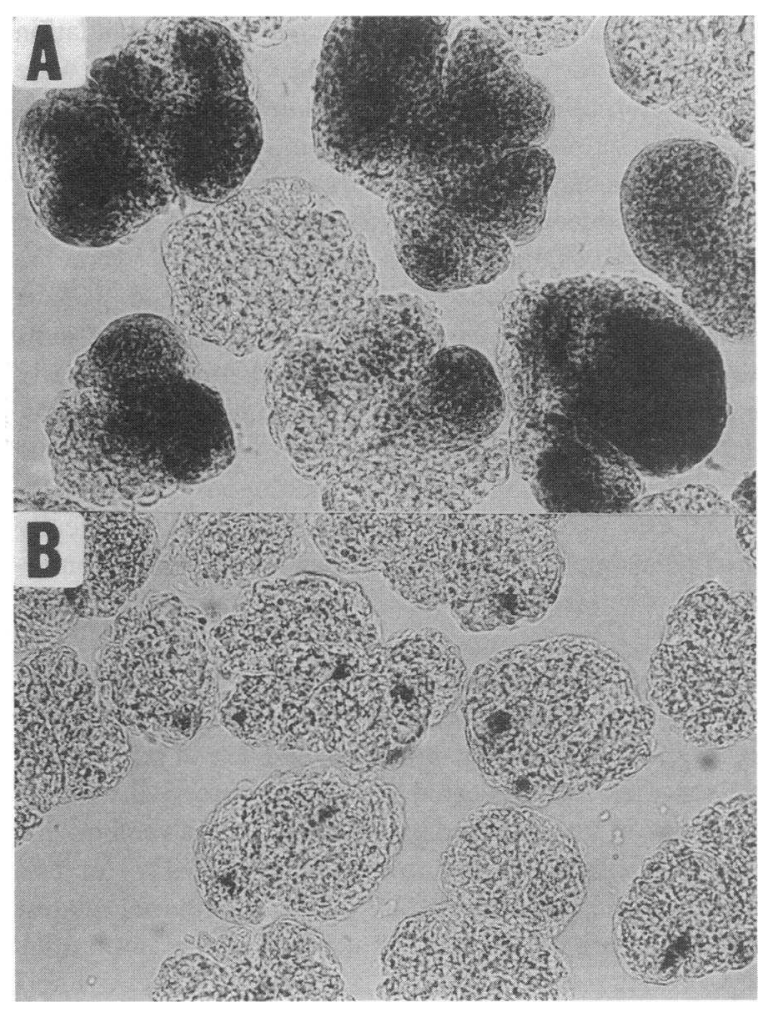

Figure 7. $\beta$-Galactosidase expression in regenerating glomeruli after transfer of replication-competent or replication-defective reporter cells. Replication-competent reporter cells $(A)$ or replication-defective cells treated with mitomycin $C(B)$ were transferred into the kidneys pretreated with monoclonal antibody 1-22-3. X-gal assay of isolated glomeruli was performed after $1 \mathrm{wk} . \times 200$; phase-contrast micrograph. 


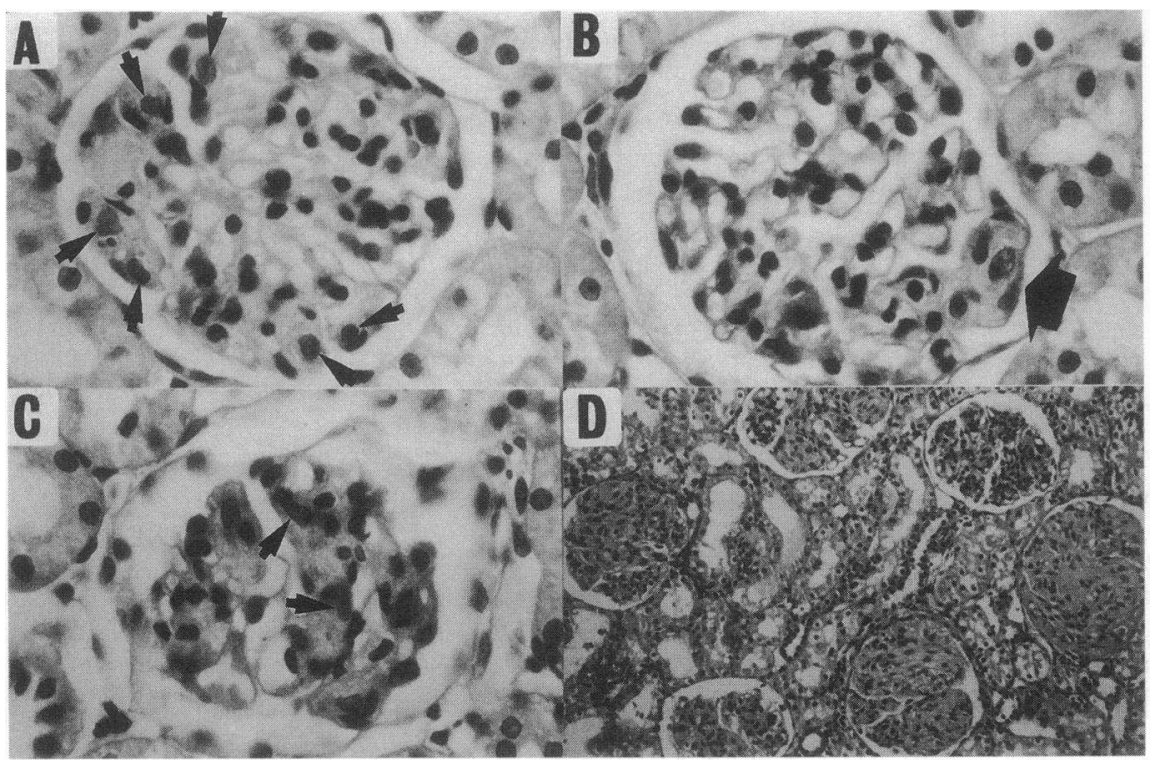

Figure 8. Histopathological analysis of the kidneys $1 \mathrm{wk}$ after transfer of reporter cells. Paraffin sections were counterstained with PAS and hematoxylin. The reporter cells exhibit large and pale nuclei distinct from intrinsic glomerular cells. Arrows indicate $(A)$ the location of reporter cells within the capillaries, $(B)$ nodular remodeling of the glomerulus, and $(C)$ reporter cells populated in the expanded glomerular tuft, in 1-22-3-untreated kidneys $(\times 1,000)$. $(D)$ Pronounced glomerular hypercellularlity with matrix accumulation is shown in the 1-22-3-treated kidney in association with reporter cell expansion $(\times 200)$.

During the study, we constantly observed site-specific accumulation of the reporter cells in the glomeruli after injection into the renal artery. Reporter cells were not detected in other portions of the injected kidneys, in the contralateral kidneys, or in other organs. In contrast to other conventional gene transfer approaches, this is a distinct advantage of the mesangial cell vector system. Using this method, the glomerulus can be targeted and functionally modified in a site-specific manner. However, we cannot exclude the possibility that a small population of the cells could have been "ectopically" trapped and were not identified on routine histological sectioning. Further investigation will be required to clarify this point.

The system we describe is not without limitations. Transfer of vector cells reduced renal function to a limited extent and induced structural changes in the glomerulus. To overcome these problems, further modification of this method will be required. For example, in this study, we used mesangial cells after prolonged culture, whereas it may be better to use early passage cells which maintain their differentiated characteristics. To obviate the risk of rejection and to allow for long-term gene expression, use of inbred strains or autologous cell transfer will also be essential. We have successfully used genetically engineered mesangial cells derived from a biopsy of the contralateral kidney for this latter purpose (our unpublished observations).

Utilization of the monoclonal antibody $1-22-3$, which induced not only the amplified gene expression but also injury of the glomerulus, should also be modified. The use of replicationdefective reporter cells revealed that the progressive damage was mainly due to uncontrolled proliferation of the vector cells. Preliminary data indicate that lower doses of 1-22-3 or cell transfer before or 1 wk after 1-22-3 treatment induces modest proliferation of vector cells and less damage of the glomerulus (our unpublished observation). Alternatively, genetic engineering of vector cells to control the growth activity could also achieve appropriate and self-limiting replication of the cells. Using these modifications, it would be possible to exert tight control over the vector cell replication in vivo allowing for expansion of the cells without causing progressive glomerular injury.
In this system, the efficiency of gene introduction varied from 17 to $67 \%$ at $4 \mathrm{~h}$ after cell injection. Several factors could affect the efficiency of this system, e.g., body weight of the recipients, cell size, injected cell number, unusual branching of the renal artery, reactive constriction of renal vasculature, or the pressure of cell injection. As far as examined, we did not detect an obvious correlation between efficiency (percentage of $\mathrm{X}$-gal-positive glomeruli) and animal size, cell number, or the pressure of injection (our unpublished data). Since unusual branching of renal artery affects the distribution of vector cells within the kidney, cell injection was performed into the renal artery in its most proximal part. Reactive constriction of renal vasculature, especially of the afferent arterioles, is a possible reason for the difference in efficiency from animal to animal. If so, combination with a vasodilator might improve the efficiency of gene transfer. We also observed that the gene transfer efficiency was improved in the regenerating glomerulus. This may be caused by increased entrapment and/or survival of the cells due to alterations in: $(a)$ diameter and length of glomerular capillaries; $(b)$ expression of adhesion molecules; or ( $c$ ) supply of growth and/or survival factors in the glomerulus.

By preconditioning of the target site with the monoclonal antibody 1-22-3, we observed amplified and prolonged expression of $\beta$-galactosidase in the glomerulus. Although macrophages infiltrating into the 1-22-3-treated glomeruli may have endogenous $\beta$-galactosidase activity, we concluded that the amplified enzymatic activity was derived exclusively from the introduced LacZ gene because: (a) no $\beta$-galactosidase activity was detected in the noninjection side of kidneys where infiltrating macrophages are present; $(b)$ injection of $\beta$-galactosidasenegative cells did not induce any $X$-gal-positive areas in the injected kidneys; and $(c)$ marked amplification of $\beta$-galactosidase activity was observed after the transfer of replication-competent reporter cells but not of replication-defective cells. These findings clearly showed that the $\beta$-galactosidase activity in the glomerular macrophages is far less than that in the established reporter cell, and that the X-gal assay we used discriminated the exogenous $\beta$-galactosidase from the endogenous enzyme. In this study, the high levels of $\beta$-galactosidase expression were detected for up to $8 \mathrm{wk}$, but frozen sections of injected kidneys 
at 4 and 8 wk exhibited evidence of glomerulosclerosis where $\mathrm{X}$-gal positivity had diminished. This discrepancy may have been due to the difficulty of isolating sclerotic glomeruli using the conventional sieving approach.

In the established reporter cells, the LacZ gene was transcribed under the control of Moloney murine leukemia virus promoter, long terminal repeat (LTR). Some reports have suggested that the viral LTR is not effective for long-term in vivo gene expression (28). Our data showed that this promoter provided sustained expression of genes in the glomerulus for up to $4 \mathrm{wk}$ with a decline thereafter. This limited expression may be due to rejection of the introduced cells since we detected histological evidence of cellular infiltration in the injected kidneys. Some investigators, however, have reported that the viral LTR becomes inactive in vivo in the absence of an immune response or host cell death $(28,29)$. Utility of the viral promoter for the purpose of long-term gene expression by this system should be evaluated further, by comparing reporter cells which express a foreign gene under the control of different regulatory elements.

In summary, we have demonstrated site-directed gene transfer into the glomerulus via a mesangial cell vector. Since mesangial cells, but not other glomerular cells, are well-characterized and can be easily cultured even from biopsy samples, they would be suitable as vectors for introducing genes into the glomerulus via autologous transplantation. This system will allow for the assessment of the pathophysiological function of specific molecules within the glomerulus and also will allow therapeutically relevant molecules to be targeted to this microscopic structure. Indeed, targeting of some genes to the glomerulus has been reported recently by Isaka (27) who used the hemagglutinating virus of Japan-liposome method to demonstrate the pathogenic roles of transforming growth factor- $\beta$ and platelet-derived growth factor in inducing glomerular injury. Sustained and/or amplified expression of site-directed exogenous genes using the mesangial cell vector system should be a powerful tool in evaluating the contribution of specific molecules to the evolution of chronic glomerular injury.

\section{Acknowledgments}

We thank Dr. A. S. Woolf and Dr. J. Price for advice on retrovirus preparation and X-gal assay; Miss M. Kolatsi for technical assistance; Dr. H. Kawachi for preparation of 1-22-3; and Dr. J. T. Norman for microscopic analyses.

This work was supported by grants from Uehara Memorial Foundation (Postdoctoral Fellowship) and Baxter Healthcare Corporation (Extramural Grant Program) to M. Kitamura.

\section{References}

1. Sedor, J. R. 1992. Cytokines and growth factors in renal injury. Semin. Nephrol. 12:428-440.

2. Baricos, W. H., and S. V. Shah. 1991. Proteolytic enzymes as mediators of glomerular injury. Kidney Int. 40:161-173.

3. Shah, S. V. 1991. Oxidant mechanisms in glomerulonephritis. Semin. Nephrol. 11:320-326.

4. Floege, J., E. Eng, B. A. Young, C. E. Alpers, T. B. Barrett, D. F. BowenPope, and R. J. Johnson. 1993. Infusion of platelet-derived growth factor or basic fibroblast growth factor induces selective glomerular mesangial cell proliferation and matrix accumulation in rats. J. Clin. Invest. 92:2952-2962.
5. Tomita, N., J. Higaki, R. Morishita, K. Kata, H. Mikami, Y. Kaneda, and T. Ogihara. 1992. Direct in vivo gene introduction into rat kidney. Biochem. Biophys. Res. Commun. 186:129-134.

6. Larrick, J. W., and K. L. Burck. 1991. Gene Therapy: Application of Molecular Biology. Elsevier Science Publishing Co., New York. Chapters 5-7.

7. Lin, H., M. S. Parmacek, G. Morle, S. Bolling, and J. M. Leiden. 1990 Expression of recombinant genes in myocardium in vivo after direct injection of DNA. Circulation. 82:2217-2221.

8. Bosch, R. J., A. S. Woolf, and L. G. Fine. 1993. Gene transfer into the mammalian kidney: direct retrovirus-transduction of regenerating tubular epithelial cells. Exp. Nephrol. 1:49-54.

9. Bandara, G., G. M. Mueller, J. Galea-Lauri, M. H. Tindal, H. I. Georgescu, M. K. Suchanek, G. L. Hung, J. C. Glorioso, P. D. Robbins, and C. H. Evans. 1993. Intraarticular expression of biologically active interleukin 1-receptor-antagonist protein by ex vivo gene transfer. Proc. Natl. Acad. Sci. USA. 90:10764-10768.

10. Tisher, C. C., and K. M. Madsen. 1991. Anatomy of the Kidney. In The Kidney. 4th ed., Vol. I. B. M. Brenner and F. C. Rector, Jr., editors. W. B. Saunders Co., Philadelphia. 3-75.

11. Remuzzi, A., B. M. Brenner, V. Pata, G. Tebaldi, R. Mariano, A. Belloro, and G. Remuzzi. 1992. Three-dimensional reconstructed glomerular capillary network: blood flow distribution and local filtration. Am. J. Physiol. 263:F562-F572.

12. Price, J., D. Turner, and C. Cepko. 1987. Lineage analysis in the vertebrate nervous system by retrovirus-mediated gene transfer. Proc. Natl. Acad. Sci. USA. $84: 156-160$

13. Morgenstern, J. P., and H. Land. 1990. Advanced mammalian gene transfer: high titre retroviral vectors with multiple drug selection markers and a complementary helper free packaging cell line. Nucleic Acid Res. 18:3587-3596.

14. Cepko, C. 1989. Lineage analysis in the vertebrate nervous system by retrovirus-mediated gene transfer. Methods Neurosci. 1:367-392.

15. Kitamura, M., T. Mitarai, N. Maruyama, R. Nagasawa, H. Yoshida, and O. Sakai. 1991. Mesangial cell behavior in a three-dimensional extracellular matrix. Kidney Int. 40:653-661.

16. Kawachi, H., M. Orisaka, K. Matsui, T. Iwanaga, S. Toyabe, T. Oite, and F. Shimizu. 1992. Epitope-specific induction of mesangial lesions with proteinuria by a MoAb against mesangial cell surface antigen. Clin. Exp. Immunol. 88:399404.

17. Chomczynski, P., and N. Sacchi. 1987. Single-step method of RNA isolation by acid guanidinium thiocyanate-phenol chloroform extraction. Anal. Biochem. 162:156-159.

18. Kitamura, M., T. Shirasawa, and N. Maruyama. 1994. Gene transfer of metalloproteinase transin induces aberrant behavior of cultured mesangial cells. Kidney Int. 45:1580-1586.

19. Maniatis, T., E. F. Fritsch, and J. Sambrook. 1989. Molecular Cloning: A Laboratory Manual. 2nd ed. Cold Spring Harbor Laboratory, Cold Spring Harbor, NY. 10.13

20. Kawachi, H., T. Iwanaga, S. Toyabe, T. Oite, and F. Shimizu. 1992. Mesangial sclerotic change with persistent proteinuria in rats after two consecutive injections of monoclonal antibody 1-22-3. Clin. Exp. Immunol. 90:129-134.

21. Orisaka, M., K. Matsui, T. Oite, and F. Shimizu. 1988. Massive proteinuria induced in rats by a single intravenous injection of a monoclonal antibody. $J$. Immunol. 141:807-814.

22. Davidson, B. L., E. D. Allen, K. F. Kozarsky, J. M. Wilson, and B. J. Roessler. 1993. A model system for in vivo gene transfer into the central nervous system using an adenoviral vector. Nature Genet. 3:219-223.

23. Cattell, W. R., J. A. W. Webb, and A. J. W. Hilson. 1989. Nuclear Medicine (Chap 5). In Clinical Renal Imaging. John Wiley \& Sons, Chichester, UK.

24. Ginsberg, J. M., B. S. Chang, R. A. Matarese, and S. Garella. 1983. Use of single voided urine samples to estimate quantitative proteinuria. N. Engl. J. Med. 309:1543-1546.

25. Bradford, M. M. 1976. A rapid and sensitive method for the quantitation of microgram quantities of protein utilizing the principle of protein-dye binding. Anal. Biochem. 72:248-254.

26. Rizzino, A. 1987. Soft agar growth assays for transforming growth factors and mitogenic peptides. In Methods in Enzymology, Peptide Growth Factors, Part A. D. Barnes and D. A. Sirbasku, editors. Academic Press Inc., Orlando. 341-352.

27. Isaka, Y., Y. Fujiwara, N. Ueda, Y. Kaneda, T. Kamada, and E. Imai. 1993. Glomerulosclerosis induced by in vivo transfection of transforming growth factor- $\beta$ or platelet-derived growth factor gene into the rat kidney. J. Clin. Invest. 92:2597-2601.

28. Palmer, T. D., G. J. Rosman, W. R. A. Osborne, and A. D. Miller. 1991. Genetically modified skin fibroblasts persist long after transplantation but gradually inactivate introduced gene. Proc. Natl. Acad. Sci. USA. 88:1330-1334.

29. Scharfmann, R., J. H. Axelrod, and I. M. Verma. 1991. Long-term in vivo expression of retrovirus-mediated gene transfer in mouse fibroblast implants. Proc. Natl. Acad. Sci. USA. 88:4626-4630. 